OPEN ACCESS

Edited by:

Francesco Maura

Cornell University, United States

Reviewed by:

Lucia Farina,

National Cancer Institute Foundation

(IRCCS), Italy

Guido Gini,

Azienda Ospedaliero Universitaria

Ospedali Riuniti, Italy

*Correspondence:

Valeria Ferla

valeria.ferla@policlinico.mi.it

Specialty section

This article was submitted to

Hematologic Malignancies,

a section of the journal

Frontiers in Oncology

Received: 21 November 2019

Accepted: 20 March 2020

Published: 08 May 2020

Citation:

Ferla V, Rossi FG, Goldaniga MC and Baldini L (2020) Biological Difference Between Epstein-Barr Virus Positive

and Negative Post-transplant

Lymphoproliferative Disorders and

Their Clinical Impact.

Front. Oncol. 10:506

doi: 10.3389/fonc.2020.00506

\section{Biological Difference Between Epstein-Barr Virus Positive and Negative Post-transplant Lymphoproliferative Disorders and Their Clinical Impact}

\author{
Valeria Ferla ${ }^{1 *}$, Francesca Gaia Rossi ${ }^{1}$, Maria Cecilia Goldaniga ${ }^{1}$ and Luca Baldini ${ }^{1,2}$ \\ ${ }^{1}$ Hematology Division, IRCCS Ca' Granda-Maggiore Policlinico Hospital Foundation, Milan, Italy, ${ }^{2}$ University of Milan, \\ Milan, Italy
}

Epstein-Barr virus (EBV) infection is correlated with several lymphoproliferative disorders, including Hodgkin disease, Burkitt lymphoma, diffuse large B-cell lymphoma (DLBCL), and post-transplant lymphoproliferative disorder (PTLD). The oncogenic EBV is present in $80 \%$ of PTLD. EBV infection influences immune response and has a causative role in the oncogenic transformation of lymphocytes. The development of PTLD is the consequence of an imbalance between immunosurveillance and immunosuppression. Different approaches have been proposed to treat this disorder, including suppression of the EBV viral load, reduction of immune suppression, and malignant clone destruction. In some cases, upfront chemotherapy offers better and durable clinical responses. In this work, we elucidate the clinicopathological and molecular-genetic characteristics of PTLD to clarify the biological differences of EBV(+) and EBV(-) PTLD. Gene expression profiling, next-generation sequencing, and microRNA profiles have recently provided many data that explore PTLD pathogenic mechanisms and identify potential therapeutic targets. This article aims to explore new insights into clinical behavior and pathogenesis of EBV $(-) /(+)$ PTLD with the hope to support future therapeutic studies.

Keywords: post-transplant lymphoproliferative disorders, Epstein-Barr virus, next-generation sequencing, microRNA, gene expression profile, tumor microenvironment

\section{INTRODUCTION}

The World Health Organization (WHO) classification of lymphoid malignancies considers four major diagnostic post-transplant lymphoproliferative disorder (PTLD) categories: early lesions, polymorphic PTLD that could be either polyclonal or monoclonal, Hodgkin lymphoma (HL), and monomorphic PTLD of which diffuse large B-cell lymphoma is most common (1).

PTLD can occur in $20 \%$ of hematopoietic stem cell (HSC) and solid organ transplant (SOT) recipients.

PTLD is associated with Epstein-Barr virus (EBV) infection in $60-80 \%$ of cases. In EBV infection in immunocompetent (IC) hosts, the virus forms an episome in latently infected B cells $(2,3)$. In post-transplant patients, immunosuppression causes T-cell inhibition with a consequent lack of T-cell modulation on B-cell proliferation. In particular, when an EBV(-) patient receives an $\mathrm{EBV}(+)$ transplant graft, immunosuppression causes uncontrolled proliferation of EBV-transformed B cells, which contributes to the development of PTLD $(2,4,5)$. 
The pathogenesis of EBV-PTLD is currently unclear; different hypotheses have been suggested as possible pathogenic mechanisms of these EBV-PTLD, such as chronic immune triggering by the graft, hit-and-run EBV infection (EBV induces chromosomal aberrations in cell genome and might be lost during malignant cell division), and other infectious agents [e.g., human herpesvirus 5,6 , or $8 ;(6-11)]$. However, there is limited evidence supporting these hypotheses (Table 1).

Clinically, there are differences between $\operatorname{EBV}(-)$ and $\operatorname{EBV}(+)$ PTLD. In particular, it has been described that EBV(-) PTLD arises later, after years of transplantation, whereas EBV $(+)$ cases arise earlier, generally after months. Furthermore, EBV RNA is detected in early and polymorphic lesions, typical lesions early after transplantation.

In the literature, contradictory data are described regarding the diversity of prognosis between the $\operatorname{EBV}(+)$ and $\operatorname{EBV}(-)$ cases; in particular, the international multicenter prospective phase 2 PTLD-1 trial found no association with overall survival and EBV status [(22, 23); Table 2].

From a therapeutic point of view, EBV(+) and EBV(-) PTLD have the same therapy; the only difference is regarding the EBVspecific adoptive immunotherapy.

Many studies have tried to investigate the genomic differences between the IC-DLBCL, EBV(+), and EBV(-) PTLD. What emerged was that EBV(-) PTLD has a genomic profile very similar to that of IC-DLBCL and a much greater biological complexity than EBV(+) PTLD (26-29).

Furthermore, it has been shown that $\operatorname{EBV}(+)$ PTLD, in addition to having a different genomic profile, has different genetic and tumor microenvironment alterations compared with those of EBV(-) PTLD (30-32).

Furthermore, EBV infection may alter the microRNA expression in B lymphocytes. MicroRNA is an important transcriptional and post-transcriptional regulator of gene expression.

In PTLD, EBV $(+)$, B-cell lymphoma revealed different microRNA profiles, compared with normal B cells or EBV lymphoblastoid cell lines generated in vitro $(33,34)$.

These considerations seem to suggest that the pathogenesis of EBV(-) PTLD is to be considered much more similar to that of IC-DLBCL and that it is less influenced by posttransplantation factors. However, despite these differences, the fact that some EBV(-) PTLD respond well to reduction of immunosuppression similarly to $\mathrm{EBV}(+)$ PTLD remains to be clarified (35). Certainly, these studies seem to offer theoretical support for future therapeutic studies in $\operatorname{EBV}(+)$ and $\operatorname{EBV}(-)$ PTLD that appear to have a different pathogenesis.

\section{THE GENOMIC LANDSCAPE OF EPSTEIN-BARR VIRUS POSITIVE AND NEGATIVE POST-TRANSPLANT LYMPHOPROLIFERATIVE DISORDERS}

In this work, we want to illustrate the genomic complexity of $\operatorname{EBV}(+)$ and $\operatorname{EBV}(-)$ PTLD through the integration of different genomic approaches that have significantly improved our understanding of the genetic landscape of these disorders (Table 3).

\section{MOLECULAR CHARACTERIZATION THROUGH A GENOMIC APPROACH}

Poirel et al. (36) studied PTLD cases with comparative genomic hybridization $(\mathrm{CGH})$ and fluorescence in situ hybridization (FISH). The overall incidence of chromosomal imbalances was described in half of PTLD cases, even in the polymorphic category. Latent EBV infection was found in the lesions of three quarters of cases. Non-random losses were 17p13; 1p36, $4 q$; and $17 q 23 q 25$, Xp. The gains of $8 \mathrm{q} 24,3 \mathrm{q} 27,2 \mathrm{p} 24 \mathrm{p} 25,5 \mathrm{p}$, $9 q 22 q 34,11,12 q 22 q 24,14 q 32,17 q$, and $18 q 21$ were the most frequent. Three amplifications $-4 \mathrm{p} 16,9 \mathrm{p} 22 \mathrm{p} 24$, and 18q21q23were detected. FISH has confirmed the involvement of $\mathrm{Bcl} 2$ in this latter imbalance. Chromosomal imbalances tended to be more complex in $\operatorname{EBV}(-)$ cases than in $\operatorname{EBV}(+)$ cases. The identification of chromosomal regions non-randomly involved in lymphomagenesis supports the role of candidate genes to be identified by a combined approach using gene expression profiling (GEP) and CGH array.

In order to improve PTLD pathogenesis understanding, Rinaldi et al. studied recurrent lesions revealed by whole-genome profiling analysis (26). The most common gains in IC-DLBCL were chromosome $3 \mathrm{q}, 7 \mathrm{q}, 12$, and $18 \mathrm{q}$ and in PTLD were chromosomes $5 \mathrm{p}$ and $11 \mathrm{p}$. The most common losses in ICDLBCL were chromosome $12 p$ and in PTLD were $6 q, 17 p$, $1 \mathrm{p}$, and 9p. DNA loss did not always match with loss of heterozygosity ( $\mathrm{LOH}$ ), and uniparental disomy seems to target chromosome 10 in PTLD. They found small deletions and gains involving BCL2 and PAX5 and ZDHHC14 (known gene). These data show that PTLD, at a lower frequency, shares common genetic aspects with IC-DLBCL. 9p13 amplification supports the importance of PAX5 in PTLD pathogenesis. Different DNA copy number and $\mathrm{LOH}$ patterns support the hypothesis that uniparental disomy can have a role in lymphomagenesis.

High-density genome-wide single-nucleotide polymorphism (SNP)-based arrays were used by Rinaldi et al. (27) to compare PTLD with IC-DLBCL and to compare $\operatorname{EBV}(+)$ with $\operatorname{EBV}(-)$ PTLD. In PTLD, the more frequently deleted loci were small interstitial deletions targeting FRA1B, FRA2E, and FRA3B fragile sites. PTLD presents typical and different aberrations than does IC-DLBCL: the deletions at 2p16.1 (FRA2E), lack of del(13q14.3) (MIR15/MIR16), and copy neutral LOH affecting 6p MHC. $\mathrm{EBV}(+)$ PTLD presented less recurrent lesions than did EBV(-) PTLD, including a gain of $7 \mathrm{p}, \operatorname{del}(4 \mathrm{q} 25-\mathrm{q} 35)$, and gains of 7q, 11q24-q25.

Menter et al. (29) investigated PTLD through next-generation sequencing (NGS) using the Ion Torrent platform. Nuclear factor- $\kappa \mathrm{B}$ pathway-related genes had fewer mutations in $\mathrm{EBV}(+)$ PTLD compared with IC-DLBCL. Moreover, in PTLD, compared with IC-DLBCL, TP53 was more frequently mutated, whereas ATM and B2M mutations were absent. TP53 mutations were more frequent in EBV(-) PTLD. Mutations in DNA damage control and immune-surveillance genes are different in PTLD 
TABLE 1 | Major risk factors in the development of PTLD.

\begin{tabular}{ll}
\hline Risk factors for PTLD & \\
\hline Infectious etiologies & EBV, especially when EBV $(-)$ recipients received a transplant graft from EBV(+) donor. \\
& Mismatch for CMV, HCV, and HHV-8, especially when they coincided with EBV infection. \\
Age and race & Ages $<10$ and $>60$ years. \\
& Race: White transplant patients $>$ Blacks. \\
Immunosuppressive therapy & The degree, duration, and type of immunosuppression (in particular, anti-thymocyte globulin, \\
& calcineurin inhibitors, anti-CD3, tacrolimus, and cyclosporine) \\
& SOT types (multi-organ and intestinal transplants have an increasing risk than have lung \\
HSCT/SOT-related factor & transplants $>$ heart transplants $>$ liver transplants $>$ pancreatic transplants $>$ kidney \\
& transplants). \\
& HLA mismatch in HSCT (haploidentical transplants have an increasing risk than have unrelated \\
& donor $>$ umbilical cord transplant $>$ HLA-identical related). \\
& Type of GVHD prophylaxis, T-cell depletion has the highest risk. \\
& Severity of GVHD transplant. \\
& Polymorphisms in cytokine genes. \\
& Recipient HLA, donor polymorphisms.
\end{tabular}

EBV, Epstein-Barr virus; CMV, cytomegalovirus; HCV, hepatitis C; HHV, human herpesvirus; HSCT, hematopoietic stem cell transplant; HLA, human leukocyte antigen; GVHD, graft-vs.-host disease; SOT, solid organ transplant.

TABLE 2 | Clinical aspects of EBV(+)/(-) PTLD.

\begin{tabular}{lll}
\hline Clinical aspects & EBV $(+) /(-)$ PTLD & References \\
\hline Incidence & $55-65 \%$ of PTLD is associated with EBV infection. & $(21,24)$ \\
Clinical & EBV(-) occur later (years) than does EBV(+) PTLD (months). \\
presentation & EBV(-) present more often as monomorphic PTLD. & $(25)$ \\
Prognosis & Controversial results in literature about the different prognoses of EBV(+)/(-) PTLD. \\
Therapy and & EBV(+) and EBV $(-)$ PTLD have the same therapy. \\
prospective & Specific immunotherapies for EBV(+) PTLD have been proposed, for example, & $(22)$ \\
& adoptive T-cell transfer, immune checkpoint inhibitors, and antiviral therapy. & $(23,25)$ \\
\hline
\end{tabular}

EBV, Epstein-Barr virus; PTLD, post-transplant lymphoproliferative disorder.

with respect to IC-DLBCL. EBV seems to have a role in the different mutational pattern.

\section{MOLECULAR CHARACTERIZATION THROUGH A TRANSCRIPTIONAL APPROACH}

Through gene expression analysis, Morscio et al. (38) and Craig et al. (30) showed that $\operatorname{EBV}(+)$ and $\operatorname{EBV}(-)$ PTLD have different microenvironment and gene expression profiles. They also demonstrated that EBV(-) PTLD and IC-DLBCL are biologically similar.

Through array comparative genome hybridization (aCGH) analysis, Ferreiro et al. (31) studied at genomic and transcriptomic levels $\mathrm{EBV}(+)$ PTLD, EBV(-) PTLD, and IC-DLBCL.

$\mathrm{EBV}(+)$ PTLD had a different CNA pattern as compared with EBV(-) PTLD and a lower genomic imbalance.

Moreover, $\mathrm{EBV}(+)$ PTLD showed distinct aCGH profiles with only one recurrent imbalance with EBV(-) PTLD. On the other hand, EBV(-) PTLD displayed similar recurrent aberrations (gain of $3 / 3 \mathrm{q}$ and $18 \mathrm{q}$ and loss of $6 \mathrm{q} 23 /$ TNFAIP3 and $9 \mathrm{p} 21 / \mathrm{CDKN} 2 \mathrm{~A}$ ) as compared with IC-DLBCL. These findings support the concept of a biological relationship between both conditions.

9p24.1 gain/amplification was the most frequent aberration in EBV(+) PTLD targeting PDCD1LG2/PDL2. These genes encode immunomodulatory programmed cell death ligands (39).

In lymphoproliferative disorder, particularly in primary mediastinal B-cell lymphoma, classical HL, and primary central nervous system lymphoma, 9p24.1 is a common copy number gain. The consequence of this alteration is an increase of PDL1 and PDL2 and their induction by JAK2 (40-43).

An upregulation of PDL1 was described in the majority of $\operatorname{EBV}(+)$ lymphomas, including PTLD (44-46). PDL1/2 signal regulates immune defenses against pathogens and T-cell tolerance/T-cell activation through the PD-1 receptor (47).

Green et al. (44) demonstrated an alternative activation mechanism of PDL1 in classical HL and EBV(+) lymphoma, in which EBV latent membrane protein 1 (LMP1) is involved in PDL1 upregulation. These results were also supported by Chen et al. (45), who demonstrated how EBV $(+)$ lymphomas, including PTLD, express detectable PDL1. In lymphomas, genomic amplification or EBV infection causes the PD-1/PDL signaling pathway activation with the immune surveillance escape (Figure 1). 
TABLE 3 | Genomic characterization of EBV(+) and EBV(-) PTLDs through different technologies approaches.

\begin{tabular}{|c|c|c|}
\hline $\begin{array}{l}\text { Genomic } \\
\text { approach }\end{array}$ & EBV(+)/EBV(-) PTLD & References \\
\hline $\begin{array}{l}\text { CGH } \\
\text { FISH } \\
\text { WGP } \\
\text { SNP } \\
\text { NGS }\end{array}$ & $\begin{array}{l}\text { The most common copy number aberration in EBV(+) PTLD is the gain/amplification of 9p24, } \\
\text { whereas in EBV(-) PTLD, it includes gain of 3/3q and 18q, loss of 6q23/TNFAIP3, and loss of } \\
\text { 9p21/CDKN2A } \\
\text { TP53 mutations were more frequent in EBV(-) PTLD than EBV(+) PTLD and IC-DLBC. } \\
\text { Compared with EBV(+) PTLD, EBV(-) PTLD and IC-DLBC have more frequent gene mutations } \\
\text { associated with the NF-kB pathway. } \\
\text { EBV(+) PTLD has a constitutive activation of the PI3K/Akt/mTOR pathway. }\end{array}$ & $\begin{array}{l}(36) \\
(26) \\
(27) \\
(31) \\
(29) \\
(37)\end{array}$ \\
\hline \multicolumn{3}{|c|}{ TRANSCRIPTIONAL APPROACH } \\
\hline $\begin{array}{l}\text { GEP } \\
\text { MicroRNA expression }\end{array}$ & $\begin{array}{l}\text { EBV }(-) \text { and } E B V(+) \text { PTLD demonstrated different GFP especially gene involved in inflammation } \\
\text { and immune response pathway profile. } \\
\text { EBV }(+) \text { PTLD has a suppressed expression of microRNA-194. }\end{array}$ & $\begin{array}{l}(38) \\
(30) \\
(31) \\
(33)\end{array}$ \\
\hline
\end{tabular}

CGH, comparative genomic hybridization; FISH, fluorescence in situ hybridization; WGP, whole-genome prediction; SNP, single-nucleotide polymorphism; NGS, next-generation sequencing; IC-DLBC, immunocompetent diffuse large B cell; GEP, gene expression profiling; NF-KB, nuclear factor-kB.

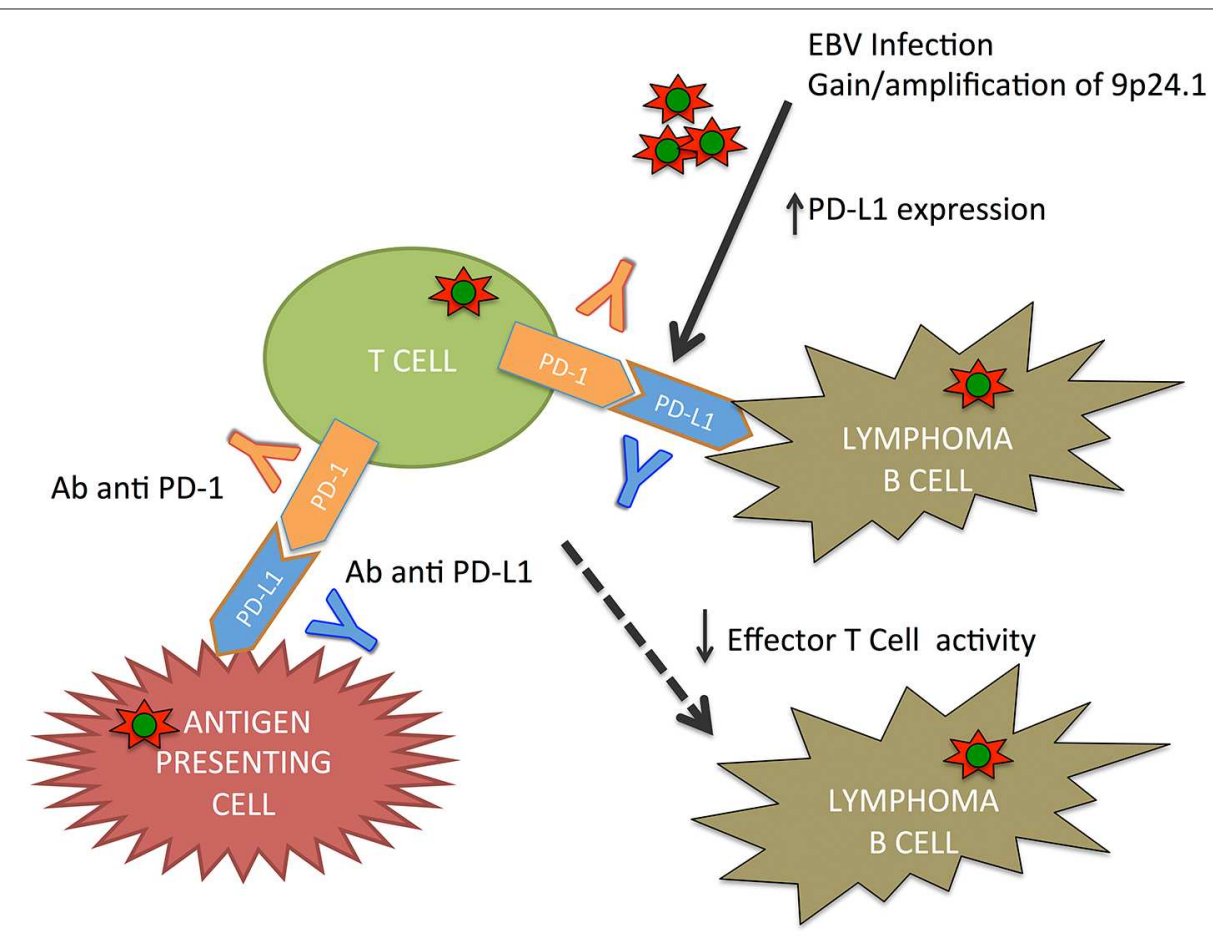

FIGURE 1 | PD-1/PD-L1 pathways in EBV(+) PTDL.

The distinctive copy number alteration in EBV $(+)$ PTLD was identified as a gain of 9p21 with respect to EBV(-) PTLD. Gain of 9p21 caused different CDKN2A expression. CDKN2A codes for cyclin-dependent kinase inhibitor 2A (p16INKA), an important regulator of the cell cycle; in particular, it decelerated cell progression through the G1 phase (48). In EBV(+) PTLD, immunohistochemistry (IHC) demonstrated that a gain of $9 \mathrm{p} 21$ was associated with exclusively cytoplasmic expression of the p16INKA protein. The p16INKA seems to be implicated in alternative oncogenic pathways and not as a tumor suppressor in $\operatorname{EBV}(+)$ PTLD $(48,49)$.
A gain of chromosome $3 / 3 q$ was found in EBV(-) PTLD, and it was absent in $\operatorname{EBV}(+)$ PTLD. This alteration caused increased expression of FOXP1 in EBV(-) PTLD; these data were confirmed by QRT-PCR and IHC. FOXP1 encodes a transcriptional regulator implicated in different biological processes and in B-cell lymphomas pathogenesis; and it seems to play a critical role in the pathogenesis of EBV(-) PTLD. However, the connection between EBV infection and FOXP1 is uncertain because EBV downregulates FOXP1 in normal B cells (50-54).

IC-DLBCL has many points in common with EBV(-) PTLD. $\mathrm{EBV}(-)$ and $\mathrm{EBV}(+)$ PTLD demonstrated different genomic 
and gene expression profiles. In particular, GEP differences in EBV(+) and EBV(-) PTLD involve inflammation and immune response pathways (31), supporting the hypothesis that the EBV infection has a major impact on the gene expression and alterations in $\operatorname{EBV}(+)$ PTLD. On the other hand, the EBV(-) PTLD appears to be more similar to de novo lymphomas arising in transplanted patients.

Many studies support the role of cytokines in the pathogenesis of $\mathrm{EBV}(+)$ PTLD (55). This hypothesis is supported by the detection of IL-10 transcripts in PTLD biopsies. B-cell lymphomas isolated from $\mathrm{EBV}(+)$ PTLD produce IL-10 in a constitutive way and use it as an autocrine growth factor (56). For this reason, serum IL-10 has been proposed as an early marker of PTLD (57-60). It is unclear why IL-10 is altered in $\operatorname{EBV}(+)$ PTLD.

EBV infection modifies microRNA expression. Gene arrays demonstrate different microRNA profiles in $\mathrm{EBV}(+)$ B-cell lymphoma lines from patients with PTLD, as compared with in vitro generated $\mathrm{EBV}(+)$ lymphoblastoid cell lines or normal B cells. In particular, microRNA-194 (33) was found to be suppressed in $\operatorname{EBV}(+)$ PTLD. MicroRNA194 overexpression increases apoptosis of $\mathrm{EBV}(+)$ B-cell lymphoma lines and attenuates IL-10 production. EBV seems to suppress microRNA-194 in order to increase IL-10 expression. Therefore, microRNA-194 may constitute a new approach to inhibiting proliferation of $\mathrm{EBV}(+)$ B-cell lymphomas in PTLD.

\section{CONCLUSIONS AND PROSPECTIVE}

In recent years, increasing understanding of the biologic and molecular PTLD pathogenesis has resulted in new therapeutic approaches and improved outcomes for these patients. Although the prognosis of $\mathrm{EBV}(+)$ in comparison with $\mathrm{EBV}(-)$ PTLD is not clear, frontline therapy in $\operatorname{EBV}(+)$ and $\operatorname{EBV}(-)$ PTLD is currently the same.

In this work, we reported much evidence that $\mathrm{EBV}(+)$ and EBV(-) PTLD have distinct genomic and transcriptomic landscape, although at the moment, clinical data do not completely support this hypothesis. EBV(-) PTLD and ICDLBCL seem to be similar biological entities; for this reason, EBV(-) PTLD might be considered as a type of lymphoma that develops coincidentally in transplant recipients. Moreover, EBV(+) PTLD and EBV(+) DLBCL present many similarities, indicating that $\mathrm{EBV}$ both infection and reactivation have important consequence on their pathogenesis $(30-32,38)$.

PTLD therapy is a combination of reduction of immunosuppressive therapy, immunotherapy, and chemotherapy $(23,25)$. In this review, we summarize the clinical and biological differences of EBV $(+)$ and EBV(-) PTLD, and we support a new therapeutic approach based on EBV status to improve outcomes of these patients.

The expression of viral antigens makes EBV $(+)$ PTLD an attractive candidate for specific therapy. Unfortunately, latent EBV-infected B cells do not express EBV-thymidine kinase transcript/protein; and for this reason, they are unaffected by antiviral agents as purine nucleoside analog. Similarly, EBVrelated lymphoproliferative disorders do not express viral protein kinase, and so monotherapy with nucleoside analogs failed to induce responses in EBV $(+)$ PTLD. However, pharmacological induction of viral thymidine kinase by the administration of the histone deacetylase inhibitor arginine butyrate, followed by antiviral therapy, has shown promising results with an acceptable toxicity profile (61).

More recently, several studies demonstrated how immunomodulatory drugs such as lenalidomide or proteasome inhibitors, in particular bortezomib, can induce EBV lytic activation $(62,63)$.

The search for new antivirals is ongoing; in particular, a new antiviral agent hexadecyloxypropyl-cidofovir (HDP-CDV) exhibits a remarkable increase in antiviral activity in vitro against different double-stranded DNA viruses including EBV (64).

Constitutive activation of the PI3K/Akt/mTOR pathway was shown in in vitro $\mathrm{EBV}(+)$ PTLD cell lines. Inhibition of either Akt or PI3K, with specific inhibitors CAL-101 or MK2206, respectively, suppresses EBV $(+)$ PTLD cell growth; and the combination of rapamycin had a synergistic effect. The combination therapy with an Akt inhibitor, or a PI3K inhibitor, and rapamycin can be an efficacious treatment for $\operatorname{EBV}(+)$ PTLD (37).

Most results presented are based on in vitro data; further evaluation and prospective clinical trials are necessary before such agents can be used as a treatment for PTLD patients.

The upfront treatment of $\mathrm{EBV}(+)$ and $\mathrm{EBV}(-)$ PTLD is the same, except for the use of EBV-specific adoptive immunotherapy. Immune-based therapies are an effective approach because of EBV antigen expression. In particular, adoptive therapy is based on the high efficacy of unselected donor lymphocyte infusions in HSC transplantation PTLD (65). Attempts were made to isolate EBV-specific cytotoxic lymphocytes (CTLs) aiming to induce a strong EBV-specific cellular immune response without the risk of graft-vs.-host disease (GVHD). Both autologous and allogeneic [isolated from the donor itself or a partial human leukocyte antigen (HLA)matched donor] CTLs, targeting specific immunogenic EBV antigens, can be used (66). In a large multicentric study, HSCT patients were treated with EBV-CTLs, either prophylactically or therapeutically (67). A Chinese prospective study in HSCT recipients demonstrated an increase in complete remission rates in patients treated with sequential administration of rituximab and EBV-CTLs (68).

Moreover, checkpoint inhibition seems to be a potential treatment option in EBV(+) PTLD. EBV infection/reactivation causes a cytotoxic T-cell dysfunction in lymphomas as PTLD and classical HL. EBV causes an upregulation of immune checkpoint markers. In classical HL, immune checkpoint inhibitors have demonstrated efficacy; and therefore, there has been an increasing interest in PTLD (69). Antigen-presenting cells express $\mathrm{PD}-\mathrm{L} 1$ that bind the $\mathrm{PD}-1$ receptor on $\mathrm{T}$ cells, thus inhibiting T-cell receptor functions. EBV plays a role in increasing PD-L1; these data support the role of checkpoint inhibition in PTLD (44). Kinch et al. demonstrated than PDL-1, PDL-2, and PD-1 were positive in more than half of PTLD cases 
following SOT (70). More clinical data are necessary to determine the safety, efficacy, and graft rejection risk or GVHD of immune checkpoint inhibitors in PTLD. Currently, a phase II trial (NCT03258567) of nivolumab in a cohort of patients-EBV $(+)$ non-HLs including EBV(+) PTLD-is ongoing.

This review summarizes many steps that have been made in understanding the $\mathrm{EBV}(+) /(-)$ PTLD biology. The biological differences connected with the EBV status support the development of preventive/preventive strategies against EBV disease and implementation of existing therapies both in the frontline and in the setting of relapsed/refractory patients. Several

\section{REFERENCES}

1. Swerdlow S, Campo E, Harris NL, Jaffe ES, Pileri S, Stein H, et al. WHO Classification of Tumours of Haematopoietic and Lymphoid Tissues. IARC (2008).

2. Nourse JP, Jones K, Gandhi MK. Epstein-Barr Virus-related post-transplant lymphoproliferative disorders: pathogenetic insights for targeted therapy. Am J Transplant. (2011) 11:888-95. doi: 10.1111/j.1600-6143.2011.03499.x

3. Jagadeesh D, Woda BA, Draper J, Evens AM. Post transplant lymphoproliferative disorders: risk, classification, and therapeutic recommendations. Curr Treat Options Oncol. (2012) 13:12236. doi: 10.1007/s11864-011-0177-x

4. Paya CV, Fung JJ, Nalesnik MA, Kieff E, Green M, Gores G, et al. Epstein-Barr virus-induced posttransplant lymphoproliferative disorders. ASTS/ASTP EBV-PTLD Task Force and The Mayo Clinic Organized International Consensus Development Meeting. Transplantation. (1999) 68:1517-25. doi: 10.1097/00007890-199911270-00015

5. McDonald RA, Smith JM, Ho M, Lindblad R, Ikle D, Grimm P, et al. Incidence of PTLD in pediatric renal transplant recipients receiving basiliximab, calcineurin inhibitor, sirolimus and steroids. Am J Transplant. (2008) 8:9849. doi: 10.1111/j.1600-6143.2008.02167.x

6. Kapelushnik J, Ariad S, Benharroch D, Landau D, Moser A, Delsol $G$, et al. Post renal transplantation human herpesvirus 8-associated lymphoproliferative disorder and Kaposi's sarcoma. Br J Haematol. (2001) 113:425-8. doi: 10.1046/j.1365-2141.2001.02740.x

7. Shimizu N, Tanabe-Tochikura A, Kuroiwa Y, Takada K. Isolation of EpsteinBarr virus (EBV)-negative cell clones from the EBV-positive Burkitt's lymphoma (BL) line Akata: malignant phenotypes of BL cells are dependent on EBV. J Virol. (1994) 68:6069-73.

8. Jox A, Rohen C, Belge G, Bartnitzke S, Pawlita M, Diehl V, et al. Integration of Epstein-Barr virus in Burkitt's lymphoma cells leads to a region of enhanced chromosome instability. Ann Oncol. (1997) 8(Suppl. 2):131-5.

9. Ambinder RF. Gammaherpesviruses and "Hit-and-Run" oncogenesis. Am J Pathol. (2000) 156:1-3. doi: 10.1016/S0002-9440(10)64697-4

10. Capello D, Cerri M, Muti G, Berra E, Oreste P, Deambrogi C, et al. Molecular histogenesis of posttransplantation lymphoproliferative disorders. Blood. (2003) 102:3775-85. doi: 10.1182/blood-2003-05-1683

11. Capello D, Rossi D, Gaidano G. Post-transplant lymphoproliferative disorders: molecular basis of disease histogenesis and pathogenesis. Hematol Oncol. (2005) 23:61-7. doi: 10.1002/hon.751

12. Tsao L, Hsi ED. The clinicopathologic spectrum of posttransplantation lymphoproliferative disorders. Arch Pathol Lab Med. (2007) 131:120918. doi: 10.1043/1543-2165(2007)131[1209:TCSOPL]2.0.CO;2

13. Opelz G, Dohler B. Lymphomas after solid organ transplantation: a collaborative transplant study report. Am J Transplant. (2004) 4:22230. doi: 10.1046/j.1600-6143.2003.00325.x

14. Nee R, Hurst FP, Dharnidharka VR, Jindal RM, Agodoa LY, Abbott KC. Racial variation in the development of posttransplant lymphoproliferative disorders after renal transplantation. Transplantation. (2011) 92:1905. doi: 10.1097/TP.0b013e3182200e8a molecular targeting agents including immunomodulatory agents, proteasome inhibitors, PI3K and Akt inhibitors, novel anti-CD20 monoclonal antibodies, and immune checkpoint inhibitors seem to have a therapeutic potential, providing a strong rationale for new clinical trials to improve the outcome of EBV post-transplant lymphoproliferative disorder.

\section{AUTHOR CONTRIBUTIONS}

All authors listed have made a substantial, direct and intellectual contribution to the work, and approved it for publication.
15. Dharnidharka VR, Sullivan EK, Stablein DM, Tejani AH, Harmon WE, North American Pediatric Renal Transplant Cooperative S. Risk factors for posttransplant lymphoproliferative disorder (PTLD) in pediatric kidney transplantation: a report of the North American Pediatric Renal Transplant Cooperative Study (NAPRTCS). Transplantation. (2001) 71:10658. doi: 10.1097/00007890-200104270-00010

16. Caillard S, Dharnidharka V, Agodoa L, Bohen E, Abbott K. Posttransplant lymphoproliferative disorders after renal transplantation in the United States in era of modern immunosuppression. Transplantation. (2005) 80:123343. doi: $10.1097 / 01 . t p .0000179639 .98338 .39$

17. Opelz G, Henderson R. Incidence of non-Hodgkin lymphoma in kidney and heart transplant recipients. Lancet. (1993) 342:15146. doi: 10.1016/s0140-6736(05)80084-4

18. Landgren O, Gilbert ES, Rizzo JD, Socie G, Banks PM, Sobocinski KA, et al. Risk factors for lymphoproliferative disorders after allogeneic hematopoietic cell transplantation. Blood. (2009) 113:4992-5001. doi: 10.1182/blood-2008-09-178046

19. Hartmann C, Schuchmann M, Zimmermann T. Posttransplant lymphoproliferative disease in liver transplant patients. Curr Infect Dis Rep. (2011) 13:53-9. doi: 10.1007/s11908-010-0145-9

20. Cockfield SM. Identifying the patient at risk for post-transplant lymphoproliferative disorder. Transpl Infect Dis. (2001) 3:708. doi: 10.1034/j.1399-3062.2001.003002070.x

21. Reshef R, Luskin MR, Kamoun M, Vardhanabhuti S, Tomaszewski JE, Stadtmauer EA, et al. Association of HLA polymorphisms with posttransplant lymphoproliferative disorder in solid-organ transplant recipients. Am J Transplant. (2011) 11:817-25. doi: 10.1111/j.1600-6143.2011.03454.x

22. Trappe R, Oertel S, Leblond V, Mollee P, Sender M, Reinke P, et al. Sequential treatment with rituximab followed by $\mathrm{CHOP}$ chemotherapy in adult Bcell post-transplant lymphoproliferative disorder (PTLD): the prospective international multicentre phase 2 PTLD-1 trial. Lancet Oncol. (2012) 13:196206. doi: 10.1016/S1470-2045(11)70300-X

23. Crombie JL, LaCasce AS. Epstein Barr virus associated B-cell lymphomas and iatrogenic lymphoproliferative disorders. Front Oncol. (2019) 9:109. doi: 10.3389/fonc.2019.00109

24. Luskin MR, Heil DS, Tan KS, Choi S, Stadtmauer EA, Schuster SJ, et al. The impact of EBV status on characteristics and outcomes of posttransplantation lymphoproliferative disorder. Am J Transplant. (2015) 15:2665-73. doi: 10.1111/ajt.13324

25. Dierickx D, Tousseyn T, Gheysens O. How I treat posttransplant lymphoproliferative disorders. Blood. (2015) 126:227483. doi: 10.1182/blood-2015-05-615872

26. Rinaldi A, Kwee I, Poretti G, Mensah A, Pruneri G, Capello D, et al. Comparative genome-wide profiling of post-transplant lymphoproliferative disorders and diffuse large B-cell lymphomas. Br J Haematol. (2006) 134:2736. doi: $10.1111 / j .1365-2141.2006 .06114 . x$

27. Rinaldi A, Capello D, Scandurra M, Greiner TC, Chan WC, Bhagat G, et al. Single nucleotide polymorphism-arrays provide new insights in the pathogenesis of post-transplant diffuse large B-cell lymphoma. Br J Haematol. (2010) 149:569-77. doi: 10.1111/j.1365-2141.2010.08125.x 
28. Morscio J, Dierickx D, Tousseyn T. Molecular pathogenesis of B-cell posttransplant lymphoproliferative disorder: what do we know so far? Clin Dev Immunol. (2013) 2013:150835. doi: 10.1155/2013/150835

29. Menter T, Juskevicius D, Alikian M, Steiger J, Dirnhofer S, Tzankov A, et al. Mutational landscape of B-cell post-transplant lymphoproliferative disorders. Br J Haematol. (2017) 178:48-56. doi: 10.1111/bjh.14633

30. Craig FE, Johnson LR, Harvey SA, Nalesnik MA, Luo JH, Bhattacharya SD, et al. Gene expression profiling of Epstein-Barr virus-positive and -negative monomorphic B-cell posttransplant lymphoproliferative disorders. Diagn Mol Pathol. (2007) 16:158-68. doi: 10.1097/PDM.0b013e31804f54a9

31. Ferreiro JF, Morscio J, Dierickx D, Vandenberghe P, Gheysens O, Verhoef $\mathrm{G}$, et al. EBV-positive and EBV-negative posttransplant diffuse large B cell lymphomas have distinct genomic and transcriptomic features. Am J Transplant. (2016) 16:414-25. doi: 10.1111/ajt.13558

32. Marcelis L, Tousseyn T. The tumor microenvironment in posttransplant lymphoproliferative disorders. Cancer Microenviron. (2019) 12:3-16. doi: 10.1007/s12307-018-00219-5

33. Harris-Arnold A, Arnold CP, Schaffert S, Hatton O, Krams SM, Esquivel CO, et al. Epstein-Barr virus modulates host cell microRNA-194 to promote IL-10 production and B lymphoma cell survival. Am J Transplant. (2015) 15:2814-24. doi: 10.1111/ajt.13375

34. Fink SE, Gandhi MK, Nourse JP, Keane C, Jones K, Crooks P, et al. A comprehensive analysis of the cellular and EBV-specific microRNAome in primary CNS PTLD identifies different patterns among EBV-associated tumors. Am J Transplant. (2014) 14:2577-87. doi: 10.1111/ajt.12858

35. Reshef R, Vardhanabhuti S, Luskin MR, Heitjan DF, Hadjiliadis D, Goral S, et al. Reduction of immunosuppression as initial therapy for posttransplantation lymphoproliferative disorder(bigstar). Am J Transplant. (2011) 11:33647. doi: 10.1111/j.1600-6143.2010.03387.x

36. Poirel HA, Bernheim A, Schneider A, Meddeb M, Choquet S, Leblond V, et al. Characteristic pattern of chromosomal imbalances in posttransplantation lymphoproliferative disorders: correlation with histopathological subcategories and EBV status. Transplantation. (2005) 80:176-84. doi: 10.1097/01.tp.0000163288.98419.0d

37. Sang AX, McPherson MC, Ivison GT, Qu X, Rigdon J, Esquivel CO, et al. Dual blockade of the PI3K/Akt/mTOR pathway inhibits posttransplant EpsteinBarr virus $B$ cell lymphomas and promotes allograft survival. Am J Transplant. (2019) 19:1305-14. doi: 10.1111/ajt.15216

38. Morscio J, Dierickx D, Ferreiro JF, Herreman A, Van Loo P, Bittoun E, et al. Gene expression profiling reveals clear differences between EBV-positive and EBV-negative posttransplant lymphoproliferative disorders. Am J Transplant. (2013) 13:1305-16. doi: 10.1111/ajt.12196

39. Sharpe AH, Wherry EJ, Ahmed R, Freeman GJ. The function of programmed cell death 1 and its ligands in regulating autoimmunity and infection. Nat Immunol. (2007) 8:239-45. doi: 10.1038/ni1443

40. Green MR, Monti S, Rodig SJ, Juszczynski P, Currie T, O’Donnell E, et al. Integrative analysis reveals selective 9p24.1 amplification, increased PD1 ligand expression, and further induction via JAK2 in nodular sclerosing Hodgkin lymphoma and primary mediastinal large B-cell lymphoma. Blood. (2010) 116:3268-77. doi: 10.1182/blood-2010-05-282780

41. Steidl C, Telenius A, Shah SP, Farinha P, Barclay L, Boyle M, et al. Genomewide copy number analysis of Hodgkin Reed-Sternberg cells identifies recurrent imbalances with correlations to treatment outcome. Blood. (2010) 116:418-27. doi: 10.1182/blood-2009-12-257345

42. Van Roosbroeck K, Cox L, Tousseyn T, Lahortiga I, Gielen O, Cauwelier $\mathrm{B}$, et al. JAK2 rearrangements, including the novel SEC31A-JAK2 fusion, are recurrent in classical Hodgkin lymphoma. Blood. (2011) 117:405664. doi: 10.1182/blood-2010-06-291310

43. Vandenberghe P, Wlodarska I, Tousseyn T, Dehaspe L, Dierickx D, Verheecke $\mathrm{M}$, et al. Non-invasive detection of genomic imbalances in Hodgkin/ReedSternberg cells in early and advanced stage Hodgkin's lymphoma by sequencing of circulating cell-free DNA: a technical proof-of-principle study. Lancet Haematol. (2015) 2:e55-65. doi: 10.1016/S2352-3026(14)00039-8

44. Green MR, Rodig S, Juszczynski P, Ouyang J, Sinha P, O’Donnell E, et al. Constitutive AP-1 activity and EBV infection induce PD-L1 in Hodgkin lymphomas and posttransplant lymphoproliferative disorders: implications for targeted therapy. Clin Cancer Res. (2012) 18:16118. doi: 10.1158/1078-0432.CCR-11-1942
45. Chen BJ, Chapuy B, Ouyang J, Sun HH, Roemer MG, Xu ML, et al. PD-L1 expression is characteristic of a subset of aggressive B-cell lymphomas and virus-associated malignancies. Clin Cancer Res. (2013) 19:3462-73. doi: 10.1158/1078-0432.CCR-13-0855

46. Veloza L, Teixido C, Castrejon N, Climent F, Carrio A, Marginet M, et al. Clinicopathological evaluation of the programmed cell death 1 (PD1)/programmed cell death-ligand 1 (PD-L1) axis in post-transplant lymphoproliferative disorders: association with Epstein-Barr virus, PD-L1 copy number alterations, and outcome. Histopathology. (2019) 75:799812. doi: 10.1111/his. 13857

47. Keir ME, Butte MJ, Freeman GJ, Sharpe AH. PD-1 and its ligands in tolerance and immunity. Annu Rev Immunol. (2008) 26:677-704. doi: 10.1146/annurev.immunol.26.021607.090331

48. LaPak KM, Burd CE. The molecular balancing act of p16(INK4a) in cancer and aging. Mol Cancer Res. (2014) 12:167-83. doi: 10.1158/1541-7786.MCR-13-0350

49. Serrano M, Lee H, Chin L, Cordon-Cardo C, Beach D, DePinho RA. Role of the INK4a locus in tumor suppression and cell mortality. Cell. (1996) 85:27-37. doi: 10.1016/s0092-8674(00)81079-x

50. Barrans SL, Fenton JA, Banham A, Owen RG, Jack AS. Strong expression of FOXP1 identifies a distinct subset of diffuse large Bcell lymphoma (DLBCL) patients with poor outcome. Blood. (2004) 104:2933-5. doi: 10.1182/blood-2004-03-1209

51. Wlodarska I, Veyt E, De Paepe P, Vandenberghe P, Nooijen P, Theate I, et al. FOXP1, a gene highly expressed in a subset of diffuse large B-cell lymphoma, is recurrently targeted by genomic aberrations. Leukemia. (2005) 19:1299-305. doi: 10.1038/sj.leu.2403813

52. Koon HB, Ippolito GC, Banham AH, Tucker PW. FOXP1: a potential therapeutic target in cancer. Expert Opin Ther Targets. (2007) 11:95565. doi: 10.1517/14728222.11.7.955

53. Price AM, Tourigny JP, Forte E, Salinas RE, Dave SS, Luftig MA. Analysis of Epstein-Barr virus-regulated host gene expression changes through primary B-cell outgrowth reveals delayed kinetics of latent membrane protein 1-mediated NF-kappaB activation. J Virol. (2012) 86:11096106. doi: 10.1128/JVI.01069-12

54. Rouhigharabaei L, Finalet Ferreiro J, Tousseyn T, van der Krogt JA, Put N, Haralambieva E, et al. Non-IG aberrations of FOXP1 in Bcell malignancies lead to an aberrant expression of $\mathrm{N}$-truncated isoforms of FOXP1. PLoS ONE. (2014) 9:e85851. doi: 10.1371/journal.pone.0 085851

55. Johannessen I, Perera SM, Gallagher A, Hopwood PA, Thomas JA, Crawford DH. Expansion in scid mice of Epstein-Barr virusassociated post-transplantation lymphoproliferative disease biopsy material. J Gen Virol. (2002) 83(Pt 1):173-8. doi: 10.1099/0022-1317-8 3-1-173

56. Beatty PR, Krams SM, Martinez OM. Involvement of IL-10 in the autonomous growth of EBV-transformed B cell lines. J Immunol. (1997) 158:4045-51.

57. Birkeland SA, Bendtzen K, Moller B, Hamilton-Dutoit S, Andersen HK. Interleukin-10 and posttransplant lymphoproliferative disorder after kidney transplantation. Transplantation. (1999) 67:876-81. doi: 10.1097/00007890-199903270-00015

58. Muti G, Klersy C, Baldanti F, Granata S, Oreste P, Pezzetti L, et al. EpsteinBarr virus (EBV) load and interleukin-10 in EBV-positive and EBV-negative post-transplant lymphoproliferative disorders. Br J Haematol. (2003) 122:92733. doi: 10.1046/j.1365-2141.2003.04540.x

59. Baiocchi OC, Colleoni GW, Caballero OL, Vettore AL, Bulgarelli A, Dalbone MA, et al. Epstein-Barr viral load, interleukin-6 and interleukin10 levels in post-transplant lymphoproliferative disease: a nested casecontrol study in a renal transplant cohort. Leuk Lymphoma. (2005) 46:5339. doi: 10.1080/10428190400027837

60. Hinrichs C, Wendland S, Zimmermann H, Eurich D, Neuhaus R, Schlattmann P, et al. IL-6 and IL-10 in post-transplant lymphoproliferative disorders development and maintenance: a longitudinal study of cytokine plasma levels and T-cell subsets in 38 patients undergoing treatment. Transpl Int. (2011) 24:892-903. doi: 10.1111/j.1432-2277.2011. 01282.x

61. Perrine SP, Hermine O, Small T, Suarez F, O'Reilly R, Boulad F, et al. A phase $1 / 2$ trial of arginine butyrate and ganciclovir in patients 
with Epstein-Barr virus-associated lymphoid malignancies. Blood. (2007) 109:2571-8. doi: 10.1182/blood-2006-01-024703

62. Jones RJ, Iempridee T, Wang X, Lee HC, Mertz JE, Kenney SC, et al. Lenalidomide, thalidomide, and pomalidomide reactivate the Epstein-Barr virus lytic cycle through phosphoinositide 3kinase signaling and ikaros expression. Clin Cancer Res. (2016) 22:4901-12. doi: 10.1158/1078-0432.CCR-15-2242

63. Granato M, Romeo MA, Tiano MS, Santarelli R, Gonnella R, Gilardini Montani MS, et al. Bortezomib promotes KHSV and EBV lytic cycle by activating JNK and autophagy. Sci Rep. (2017) 7:13052. doi: 10.1038/s41598-017-13533-7

64. Hostetler KY. Synthesis and early development of hexadecyloxypropylcidofovir: an oral antipoxvirus nucleoside phosphonate. Viruses. (2010) 2:2213-25. doi: 10.3390/v2102213

65. Papadopoulos EB, Ladanyi M, Emanuel D, Mackinnon S, Boulad F, Carabasi $\mathrm{MH}$, et al. Infusions of donor leukocytes to treat Epstein-Barr virus-associated lymphoproliferative disorders after allogeneic bone marrow transplantation. $N$ Engl J Med. (1994) 330:1185-91. doi: 10.1056/NEJM199404283 301703

66. Bollard CM, Heslop HE. $\mathrm{T}$ cells for viral infections after allogeneic hematopoietic stem cell transplant. Blood. (2016) 127:3331-40. doi: 10.1182/blood-2016-01-628982

67. Heslop HE, Slobod KS, Pule MA, Hale GA, Rousseau A, Smith CA, et al. Long-term outcome of EBV-specific T-cell infusions to prevent or treat EBVrelated lymphoproliferative disease in transplant recipients. Blood. (2010) 115:925-35. doi: 10.1182/blood-2009-08-239186
68. Jiang X, Xu L, Zhang Y, Huang F, Liu D, Sun J, et al. Rituximab-based treatments followed by adoptive cellular immunotherapy for biopsy-proven EBV-associated post-transplant lymphoproliferative disease in recipients of allogeneic hematopoietic stem cell transplantation. Oncoimmunology. (2016) 5:e1139274. doi: 10.1080/2162402X.2016.1139274

69. Armand P. Immune checkpoint blockade in hematologic malignancies. Blood. (2015) 125:3393-400. doi: 10.1182/blood-2015-02-567453

70. Kinch A, Sundstrom C, Baecklund E, Backlin C, Molin D, Enblad G. Expression of PD-1, PD-L1, and PD-L2 in posttransplant lymphoproliferative disorder after solid organ transplantation. Leuk Lymphoma. (2019) 60:37684. doi: 10.1080/10428194.2018.1480767

Conflict of Interest: The authors declare that the research was conducted in the absence of any commercial or financial relationships that could be construed as a potential conflict of interest.

The reviewer LF declared a past co-authorship with author LB to the handling Editor.

Copyright () 2020 Ferla, Rossi, Goldaniga and Baldini. This is an open-access article distributed under the terms of the Creative Commons Attribution License (CC BY). The use, distribution or reproduction in other forums is permitted, provided the original author(s) and the copyright owner(s) are credited and that the original publication in this journal is cited, in accordance with accepted academic practice. No use, distribution or reproduction is permitted which does not comply with these terms. 